\title{
Identification of acid-tolerant coffee genotypes in a coffee germplasm collection of Colombia
}

\author{
Ricardo Acuña-Zornosa1 (iD), Siavosh Sadeghian-Khalajabadi² $^{(i)}$
}

\begin{abstract}
${ }^{1}$ National Coffee Research Center-CENICAFE, Head of Plant Physiology, Planalto, km 4 vía Chinchiná-Manizales, Manizales, Caldas, Colombia ${ }^{2}$ National Coffee Research Center-CENICAFE, Head of Soil Sciences, Planalto, km 4 vía Chinchiná-Manizales, Manizales, Caldas, Colombia Contact authors: ricardo.acuna@cafedecolombia.com, siavosh.sadeghian@cafedecolombia.com

Received in February 26, 2020 and approved in August 17, 2020
\end{abstract}

\section{ABSTRACT}

One of the limitations of coffee production in many regions of Colombia is the soil acidity. According to historical soil chemical analysis records, more than $50 \%$ of coffee farms have $\mathrm{pH}$ values below 5.0. Because acid-tolerant coffee varieties are not available, farmers use calcareous additives to correct the problem, which incurs associated labor and input costs. The objective of this work was to identify acid-tolerant genotypes of Coffea arabica. For two contrasting soils in the coffee-growing area of Colombia (Andisol and Entisol), the effect of soil acidity on the growth of 20 genotypes of Coffea arabica during the seedling stage was evaluated. The genotypes were wild accessions that make up the Colombian Coffee Germplasm Collection and the Castil$10^{\circ}$ Naranjal Variety, used as commercial material. Six months after the seedlings were transplanted into soils treated with or without acidity correction additives, the weight of the dry matter of the roots, stems and leaves was recorded. Later, the acid-tolerant genotypes were identified by means of the quadrant method and the tolerance index. The Timor Hybrid and Rume Sudan genotypes were identified as tolerant of the acidity of the two soil types. These genotypes could be used as progenitors in a coffee breeding program leading to a commercial coffee variety tolerant to soil acidity.

Key words: Andisol; entisol; Coffea arabica L.; timor hybrid; rume sudan.

\section{INTRODUCTION}

Soil acidity limits global crop production to approximately $30 \%$ of the Earth's surface, which corresponds to $50 \%$ of the world's potentially cultivable land. The tropical and subtropical zones represent $60 \%$ of the world's acidic soils. In tropical regions, approximately $43 \%$ of soils are acidic, with $68 \%$ of these soils found in tropical America (Yang; Rao; Horst, 2013). In addition to containing toxic levels of aluminum $\left(\mathrm{Al}^{3+}\right)$ and manganese $\left(\mathrm{Mn}^{2+}\right)$, acidic soils are deficient in nutrients, especially calcium $\left(\mathrm{Ca}^{2+}\right)$, magnesium $\left(\mathrm{Mg}^{2+}\right)$ and phosphorus (P), which affect crop development and productivity (Havlin et al., 2014; Rao, 2014; Rao et al., 2016).

According to soil analysis records from the Colombian coffee grower zone performed over the last 20 years, a high percentage of the tested samples had $\mathrm{pH}$ values lower than 5.0 and $\mathrm{Al}^{3+}$ levels greater than $1.0 \mathrm{cmol}_{\mathrm{c}} \mathrm{kg}^{-1}$ (Sadeghian, 2013). Fifty-two percent of coffee-growing areas corresponded to volcanic ash-derived, P-fixing, high organic matter content soils with iron and aluminum oxides, hydroxides and $\mathrm{pH}$ values lower than 5.5, all of which are factors that negatively affect nutrient availability for coffee plants (Valencia, 1999). At the rainiest sites in the Colombian coffee-growing region, great losses occur through the leaching of alkali or basic cations such as $\mathrm{Ca}, \mathrm{Mg}$ and $\mathrm{K}$, which are replaced by acidic cations, mainly $\mathrm{H}, \mathrm{Al}, \mathrm{Fe}$ and $\mathrm{Mn}$. Organic matter decomposition, sulfur oxidation and ammonium nitrification are also naturally occurring processes that contribute to the increased soil acidity in these regions (Zapata, 2004). Similar effects have been observed in $C$. arabica plantations in Indonesia (Hanisch et al., 2012). For the growth of coffee in Colombia, specifically in relation to the seedling stage, soils with $\mathrm{pH}$ values between 4.9 and 5.7 and $\mathrm{Al}^{3+}$ contents of less than $1.10 \mathrm{cmol}_{\mathrm{c}} \mathrm{kg}^{-1}$ are considered adequate (Sadeghian; Díaz, 2020).

The use of lime, phosphorus fertilizers and organic inputs is recommended to correct the soil acidity and provide deficient nutrients, and this is practiced in many agricultural systems in temperate and tropical climates. Although liming can raise the soil $\mathrm{pH}$ and remediate low surface acidity, the subsoil is typically not affected because the deep incorporation of lime is technically difficult and expensive, making it a controversial alternative, in addition to the fact that the continued use of agrochemicals has side effects that cast doubt on their environmental sustainability (Rao, 1993; Rao, 2014; Rheinheimer et al., 2000).

An integrated soil management program that includes site-specific additives and the use of microorganisms and commercial products to correct soil acidity is a strategy to address soil acidification, although these practices would result in additional costs for farmers. In view of the above, the genetic mechanisms that plants have developed to tolerate acidity could be exploited and genotypes that can be used for the production of new acid-tolerant varieties could be identified. The incorporation of these varieties into an integrated soil management program would increase efficiency, mitigate environmental impacts and reduce production costs for farmers. 
The Colombia National Coffee Research Center (CENICAFÉ) has a coffee germplasm collection composed of more than 1,000 accessions, which includes different species, hybrids, varieties and elite genotypes of Coffea sp. However, no studies focused on identifying genotypes tolerant to the acidic soil conditions have been conducted with this collection. Therefore, the present study evaluated 20 genotypes representative of the genetic variability of the collection, which were grown in two soil types with low acidity, and genotypes that showed tolerance to this physiological stress were identified.

\section{MATERIAL AND METHODS}

\subsection{Plant material}

A total of 19 genotypes were randomly selected from the list of 54 genotyped accessions that make up the core of the coffee germplasm collection and are grouped using the nearest neighbor method according to pairwise genetic distance (Moncada and Maldonado, personal communication). These genotypes are part of the Germplasm Bank of CENICAFE and are wild accessions of $C$. arabica that were collected in several African expeditions in the 1960s. The Castillo ${ }^{\circledR}$ Naranjal variety, which is resistant to coffee rust and has been grown since 2005 in the central Colombian coffee-growing region, was used as a commercial genotype (Alvarado et al., 2006).

\subsection{Soill}

In a coffee farm in the municipality of Cubarral (Meta, Colombia) and in the Naranjal Experimental Station (municipality of Chinchiná, Caldas, Colombia), $2.0 \mathrm{t}$ of soil at a depth of $0.20 \mathrm{~m}$ were collected. These soils, classified as Entisol and Andisol, respectively, were characterized as being acidic for coffee cultivation and had contrasting properties. The amount of dolomitic limestone required to correct the acidity in each case was determined according to the $\mathrm{pH}$ value. Subsequently, half of the soils were limed, watered and incubated for one month, after which time their physicochemical characteristics were determined (Table 1) according to the methods described by Carrillo (1985).

\subsection{Sowing of genotypes}

Seeds were collected from the 19 genotypes of the Colombian Coffee Germplasm Collection and from the Castillo $^{\circledR}$ Naranjal variety used as commercial material. Germinators were set up and when seedlings were obtained, they were planted in $0.17 \mathrm{~m} \times 0.23 \mathrm{~m}$ black plastic bags, according to the soil type and acidity condition. Subsequently, the plants were placed in a flat area covered with shade cloth that allowed transmission of $43 \%$ of the photosynthetically active radiation. Agronomic plant management was performed according to the technical recommendations of CENICAFE, applying $0.002 \mathrm{~kg}$ plant $^{-1}$ of diammonium phosphate (DAP) fertilizer at two and four months (Sadeghian, 2008; Gaitán et al., 2013). At six months, the plants were collected, soil residues were removed, and the plant height and root length of each plant were measured. The plants were individually packed in paper bags, labeled according to the treatment and dried in an oven at $75^{\circ} \mathrm{C}$ for $72 \mathrm{~h}$. The weight of the dry biomass of each plant was measured using an analytical balance $\left(1 \times 10^{-6} \mathrm{~kg}\right)$.

Table 1: Physicochemical characteristics of the Entisol and Andisol used for the evaluation of acid-tolerant $C$. arabica genotypes.

\begin{tabular}{ccccc}
\hline & \multicolumn{2}{c}{ Andisol (Naranjal) } & \multicolumn{2}{c}{ Entisol (Cubarral) } \\
\hline & Acidic & Amended & Acidic & Amended \\
\hline $\mathrm{pH}$ & 4.50 & 5.20 & 3.90 & 5.20 \\
$\mathrm{~K}\left(\mathrm{cmol}_{\mathrm{c}} \mathrm{kg}^{-1}\right)$ & 0.40 & 3.87 & 1.80 & 3.68 \\
$\mathrm{Ca}\left(\mathrm{cmol}_{\mathrm{c}} \mathrm{kg}^{-1}\right)$ & 1.62 & 3.94 & 0.58 & 5.53 \\
$\mathrm{Mg}\left(\mathrm{cmol}_{\mathrm{c}} \mathrm{kg}^{-1}\right)$ & 0.36 & 1.32 & 0.19 & 2.06 \\
$\mathrm{Na}\left(\mathrm{cmol}_{\mathrm{c}} \mathrm{kg}^{-1}\right)$ & 0.02 & 0.14 & 0.02 & 0.13 \\
$\mathrm{Al}\left(\mathrm{cmol}_{\mathrm{c}} \mathrm{kg}^{-1}\right)$ & 0.90 & 0.20 & 1.00 & 0.20 \\
$\mathrm{P}\left(\mathrm{kg} \mathrm{kg}^{-1}\right)$ & $6 \times 10^{-6}$ & $9 \times 10^{-6}$ & $1.29 \times 10^{-4}$ & $9.9 \times 10^{-4}$ \\
Organic matter $(\%)$ & \multicolumn{3}{c}{7.0} & \multicolumn{3}{c}{5.0} \\
Texture & \multicolumn{3}{c}{ Loamy, sandy } & \multicolumn{3}{c}{ Loamy, sandy, clayey } \\
\hline
\end{tabular}

\subsection{Experimental design}

A total of 25 experimental units were planted per treatment, and the number of replicates was statistically defined according to the following criteria determined in previous CENICAFE experiments: estimated variance of 4.687 associated with the total dry matter weight in six-monthold seedlings; minimum significant difference of 0.0015 $\mathrm{kg}$; level of significance of $5 \%$ and reliability of $89 \%$. The response variable was the dry matter weight, and plant height and root length recorded at six months of cultivation were the complementary variables. The effect of the treatments was evaluated by two methods used by the International Center for Tropical Agriculture-CIAT for the development of varieties tolerant to acidic soil (Howeler, 1990; Nicholaides; Piha, 1990).

Quadrant method: A Cartesian coordinate was constructed (Figure 1) in which the dry matter under acidic soil conditions is represented by the $\mathrm{X}$-axis and the relative biomass (\%) by the Y-axis. The latter corresponds to the relationship between the dry biomass in the unlimed soil and the dry biomass in the amended soil, expressed as a percentage. Then, the area of the figure delimited by these axes was divided horizontally into two by a line drawn at the $80 \%$ relative biomass level (Y-axis) to separate the acidtolerant genotypes (above the line) from the acid-sensitive 
genotypes (below the line). The literature suggests using $80 \%$ relative biomass to assess the tolerance to acidic soil, but if the researcher requires a stricter criterion, this line can be drawn at the $85 \%$ level. Lastly, a line was drawn vertically through the $\mathrm{X}$-axis at the level of the mean dry matter weight of the best one-third of the genotypes sown in the amended soil, forming four areas or quadrants in the figure. The genotypes that were distributed in quadrant IV were selected as tolerant to acidic soil (Nicholaides; Piha,1990).

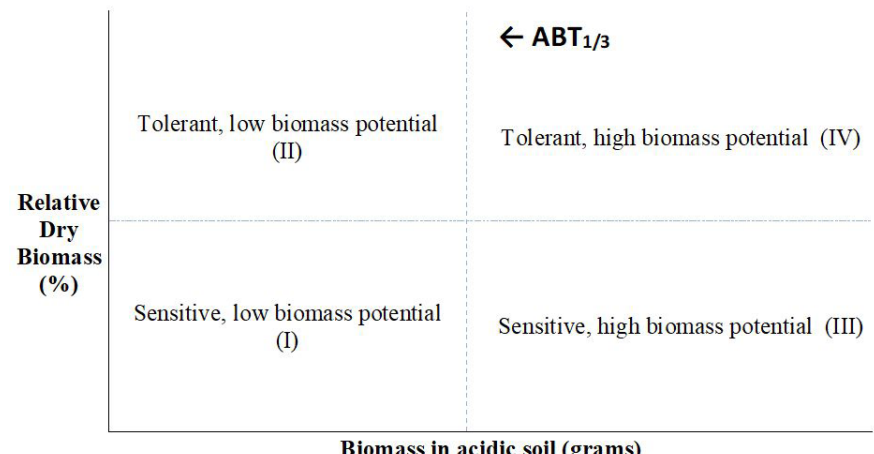

Figure 1: Model of the quadrant method used to differentiate genotypes according to their tolerance to soil acidity and their biomass potential under these stress conditions. Relative dry biomass $=$ (dry biomass weight without liming/dry biomass weight with lime); $A B T_{1 / 3}$ is the average biomass of the top onethird of the genotypes in soil treated with lime (Nicholaides; Piha, 1990).

Tolerance index method: This index was calculated using equation (1). Genotypes with a tolerance index greater than or equal to 1.0 were selected as tolerant to acidic soil (Howeler, 1990).

Tolerance index $=\frac{\text { Dry biomass without lime }}{\text { Dry biomass with lime }} * \frac{\text { Mean dry biomass without lime }}{\text { Maximum dry biomass without lime }}$

Selection of tolerant $C$. arabica genotypes: Genotypes that were distributed in quadrant IV and had a tolerance index greater than 1 were selected as progenitors for a breeding strategy for acidic soil tolerance. With the complementary variables, plant height and root length, a $t$-test $(95 \%)$ was performed comparing each population with respect to the overall mean of their corresponding acidity condition.

\section{RESULTS AND DISCUSSION}

\subsection{Soill properties}

The soil properties analyzed before and after liming are shown in Table 1 . In the two soil samples, the initial exchangeable aluminum content $\left(\mathrm{Al}^{3+}\right)$ was practically the same $\left(1 \mathrm{cmol}_{\mathrm{c}} \mathrm{kg}^{-1}\right)$, while the $\mathrm{pH}$ of the Entisol was lower (3.8) than that of the Andisol (4.5). The Entisol had a significantly higher phosphorus content $\left(1.29 \times 10^{-4} \mathrm{~kg} \mathrm{~kg}^{-1}\right)$ compared to the Andisol (6 x 10-6 $\left.\mathrm{kg} \mathrm{kg}^{-1}\right)$, and it is known that inert phosphorus, aluminum, iron and non-apatite calcium phosphates predominate in Entisols. As expected, the organic matter content was higher in the Andisol. In terms of physical differences, the Entisol exhibited a sandy-loamy-clayey texture and a brownish yellow color, while the Andisol was sandy-loamy and black.

Liming was used to correct soil acidity (by increasing $\mathrm{pH}$ and neutralizing $\mathrm{Al}^{3+}$ ) to the adequate range for coffee cultivation (Sadeghian, 2013) and to increase the $\mathrm{Ca}^{2+}, \mathrm{Mg}^{2+}$ and $\mathrm{K}^{+}$levels (Table 1 ). The results showed the benefits of applying dolomite to acidic soils and confirmed reports in previous studies on coffee cultivation (Valencia; Bravo, 1981; Correa et al., 2007; Vilela et al., 2010).

\subsection{Plant Biomass}

Table 2 shows the mean dry biomass values of the genotypes grown in Entisol and Andisol under the two soil acidity levels. A positive response was observed in approximately $35 \%$ of the genotypes planted in Entisol soil when lime was applied. Table 2 also shows the mean dry matter values of the genotypes grown in Andisol. In this case, the biomass increased with acidity correction in $35 \%$ of the genotypes.

\subsection{Selection of acid-tolerant genotypes}

\subsubsection{Quadrant method}

In both soil types, there was variability in the tolerance to acidity of the cultivated genotypes, a result that is evidenced by the dispersal of the wild coffee accessions throughout quadrants I, II and IV (Figures 2 and 3). The Timor Hybrid, S-17 Irgalem and Rume Sudan genotypes were distributed in quadrant IV, indicating tolerance to acidity in Entisol (Figure 2). For Andisol, the E146, Castillo Naranjal, S-17 Irgalem, Timor Hybrid and Rume Sudan genotypes were distributed in quadrant IV (Figure 3).

\subsubsection{Tolerance Index Method:}

Table 3 describes the results obtained for the tolerance indices of the genotypes grown in the two soil types under acidic conditions. In Entisol, the S-17 Irgalem, Timor Hybrid and Rume Sudan genotypes had an index greater than 1.0, while in Andisol, the E146, E085 and Timor Hybrid genotypes had a tolerance index greater than 1.0; however, the Rume Sudan genotype obtained a value of 0.98 . 
Table 2: Mean dry matter of genotypes grown in Entisol with $\mathrm{pH} 3.9$ and corrected with lime to $\mathrm{pH} 5.2$ in Andisol with pH 4.5 and corrected with lime to $\mathrm{pH} 5.2$; SE = standard error.

\begin{tabular}{|c|c|c|c|c|c|c|c|c|}
\hline \multirow{3}{*}{ GENOTYPE } & \multicolumn{4}{|c|}{ ENTISOL } & \multicolumn{4}{|c|}{ ANDISOL } \\
\hline & \multicolumn{4}{|c|}{ Dry matter $\left(\mathrm{kg}_{\text {plant }}{ }^{-1}\right)$} & \multicolumn{4}{|c|}{ Dry matter $\left(\mathrm{kg}_{\text {plant }}{ }^{-1}\right)$} \\
\hline & ACIDIC & SE & AMENDED & SE & ACIDIC & SE & MENDED & SE \\
\hline E364 & 0.00302 & 0.00042 & 0.00294 & 0.00038 & 0.00088 & 0.00022 & 0.00121 & 0.00046 \\
\hline E365 & 0.00295 & 0.00046 & 0.0034 & 0.00051 & 0.00378 & 0.00062 & 0.00208 & 0.00037 \\
\hline E336 & 0.00328 & 0.0005 & 0.00467 & 0.00041 & 0.00308 & 0.00043 & 0.00266 & 0.00054 \\
\hline E146 & 0.00411 & 0.00039 & 0.00709 & 0.00052 & 0.00625 & 0.00041 & 0.00481 & 0.0005 \\
\hline E290 & 0.00481 & 0.00064 & 0.00621 & 0.00058 & 0.00357 & 0.00036 & 0.00432 & 0.00044 \\
\hline E085 & 0.00465 & 0.00051 & 0.00398 & 0.00056 & 0.00528 & 0.00064 & 0.00341 & 0.00064 \\
\hline E071 & 0.00315 & 0.0003 & 0.00354 & 0.00045 & 0.00343 & 0.00026 & 0.00254 & 0.00041 \\
\hline E042 & 0.0023 & 0.00026 & 0.0033 & 0.00035 & 0.00385 & 0.0005 & 0.00363 & 0.00059 \\
\hline E428 & 0.00279 & 0.00023 & 0.00293 & 0.0004 & 0.00292 & 0.00022 & 0.00395 & 0.00035 \\
\hline E114 & 0.00233 & 0.00019 & 0.00353 & 0.00038 & 0.00329 & 0.00022 & 0.00383 & 0.00037 \\
\hline $\mathrm{E} 420$ & 0.00415 & 0.00029 & 0.00323 & 0.00037 & 0.00239 & 0.00027 & 0.0012 & 0.00034 \\
\hline E554 & 0.00309 & 0.00021 & 0.0038 & 0.00043 & 0.00493 & 0.00027 & 0.00535 & 0.0004 \\
\hline ET57 & 0.00523 & 0.00049 & 0.00334 & 0.00055 & 0.00354 & 0.00028 & 0.00396 & 0.00046 \\
\hline ET06 & 0.00563 & 0.00039 & 0.00442 & 0.00042 & 0.00512 & 0.00046 & 0.0051 & 0.00044 \\
\hline ET27 & 0.00324 & 0.00023 & 0.00546 & 0.00036 & 0.00472 & 0.00027 & 0.00406 & 0.0006 \\
\hline SL-28 & 0.00609 & 0.00059 & 0.00535 & 0.00044 & 0.00525 & 0.00036 & 0.00386 & 0.00043 \\
\hline Castillo Naranjal & 0.0059 & 0.00047 & 0.00667 & 0.00058 & 0.00614 & 0.00058 & 0.00555 & 0.00047 \\
\hline S-17 Irgalem & 0.00643 & 0.00055 & 0.0026 & 0.00037 & 0.00381 & 0.00053 & 0.00285 & 0.00037 \\
\hline Timor Hybrid & 0.00642 & 0.0007 & 0.00342 & 0.00043 & 0.00645 & 0.00055 & 0.00481 & 0.00067 \\
\hline Rume Sudan & 0.00756 & 0.0006 & 0.00489 & 0.00059 & 0.00726 & 0.00041 & 0.00735 & 0.00071 \\
\hline
\end{tabular}

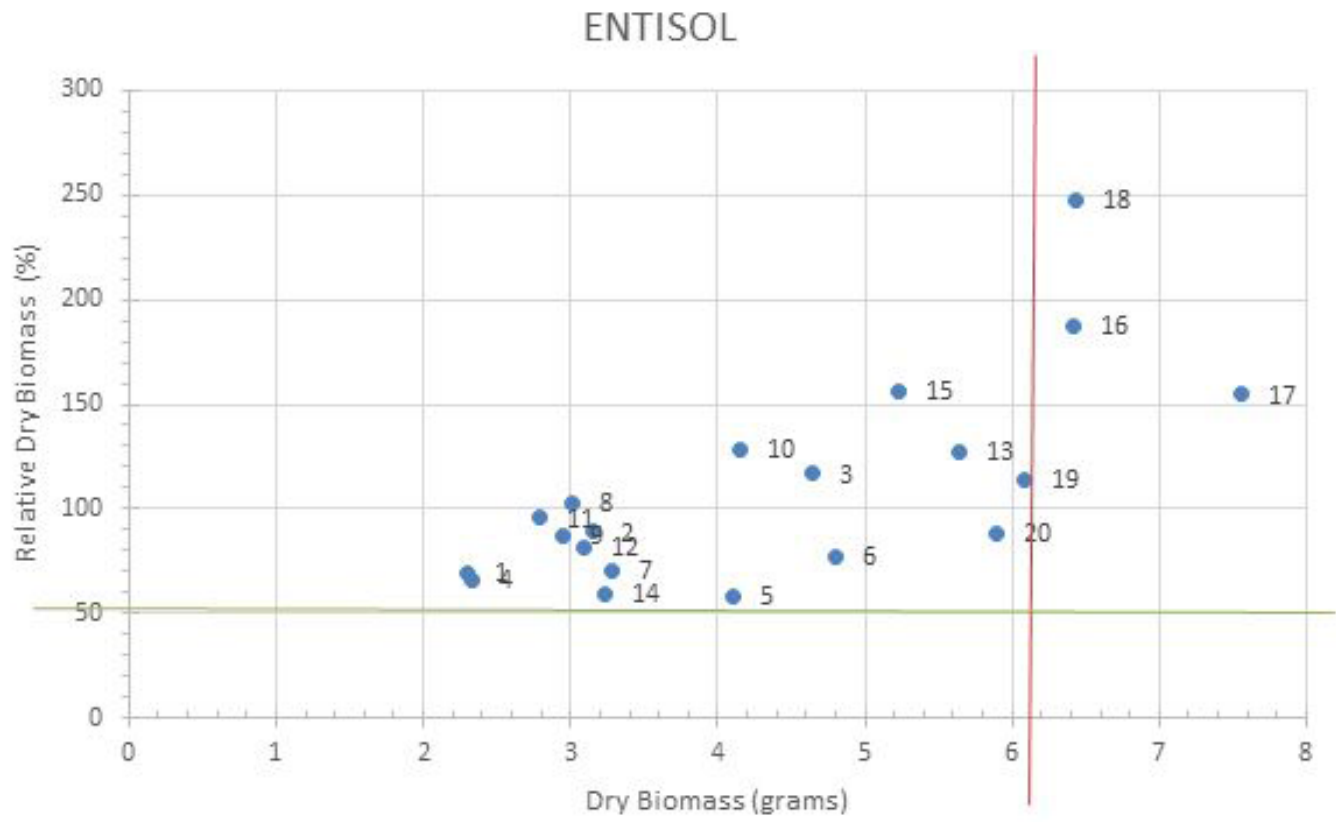

Figure 2: Quadrant model for the selection of C. arabica genotypes tolerant to acidic Entisol soil. Genotypes 16,17 and 18 were distributed in the upper right quadrant (IV) and were considered acid tolerant. 1: E042, 2: E071, 3: E085, 4: E114, 5: E146, 6: E290, 7: E336, 8: E364, 9: E365, 10: E420, 11: E428, 12: E554, 13: ET06, 14: ET27, 15: ET57, 16: Timor Hybrid, 17: Rume Sudan, 18: S17-Irgalem, 19: SL-28, 20: Castillo Naranjal. 


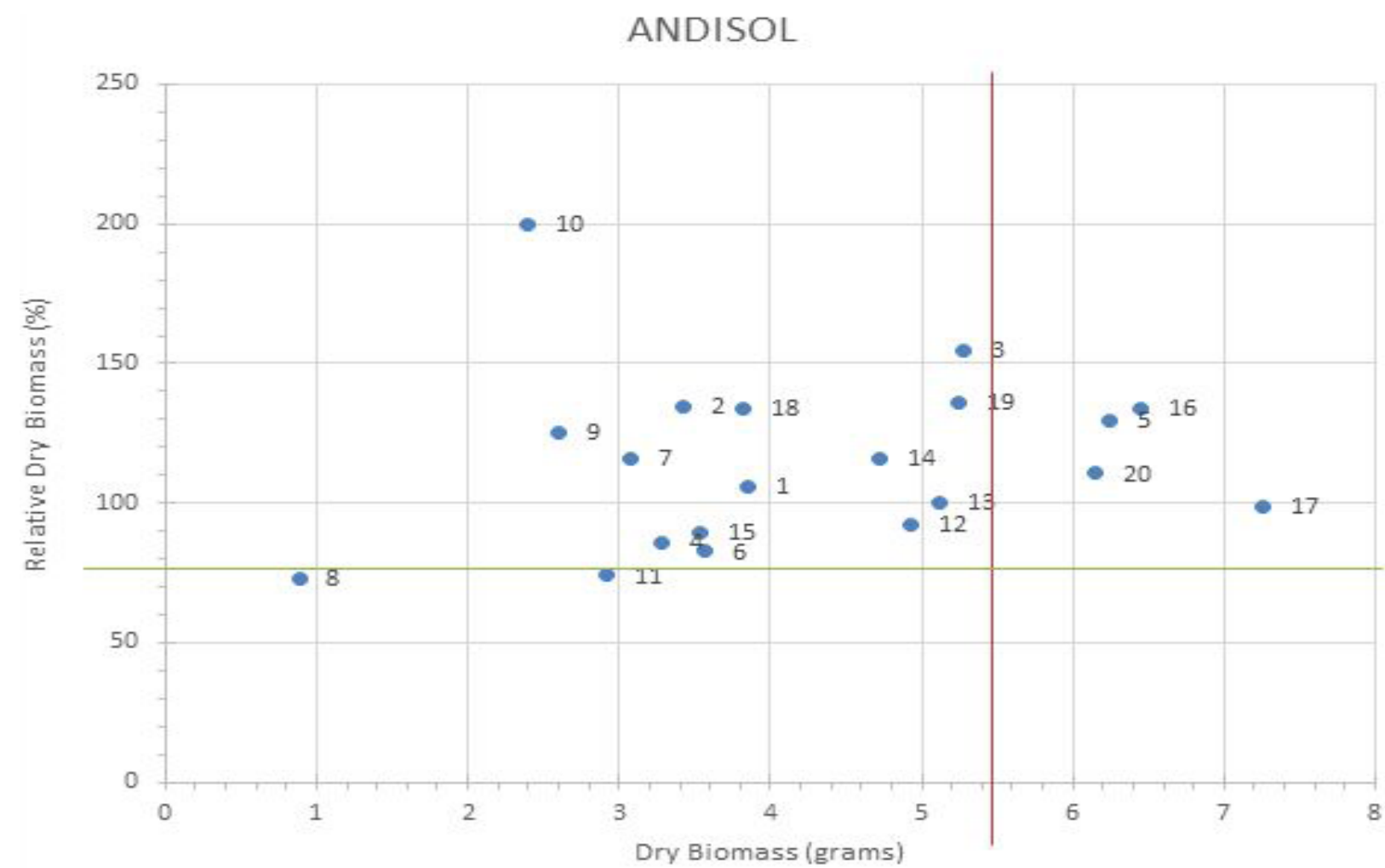

Figure 3: Quadrant model for the selection of C. Arabica genotypes tolerant to acidic Andisol soil. Genotypes 5, 16,17 and 20 were distributed in the upper right quadrant (IV) and were considered acid tolerant. 1: E042, 2: E071, 3: E085, 4: E114, 5: E146, 6: E290, 7: E336, 8: E364, 9: E365, 10: E420, 11: E428, 12: E554, 13: ET06, 14: ET27, 15: ET57, 16: Timor Hybrid, 17: Rume Sudan, 18: S17-Irgalem, 19: SL-28, 20: Castillo Naranjal.

Considering the results obtained through the application of both methods, the Rume Sudan, Timor Hybrid and S-17 Irgalem genotypes were preselected as acid tolerant in Entisol. These three genotypes were distributed in quadrant IV and had tolerance indices $>1$. The Rume Sudan genotype had the highest dry biomass $(0.00756 \mathrm{~kg} ; \mathrm{P}(T<=t) 0.04)$ and the greatest height $(0.438 \mathrm{~m} ; \mathrm{P}(T<=t) 0.04)$, followed by the S-17 Irgalem $(0.00643 \mathrm{~kg})$ and Timor Hybrid $(0.00642 \mathrm{~kg})$ genotypes. Regarding root lengths, no significant differences were found among these three genotypes (Table 4).

The Rume Sudan, Timor Hybrid, E146 and E085 genotypes were preselected as acid tolerant in Andisol. The four genotypes were distributed in quadrant IV and had tolerance indices $>1.0$ except for the Rume Sudan genotype, which had an index of 0.98. However, Rume Sudan had the highest dry biomass $(0.00726 \mathrm{~kg} ; \mathrm{P}(T<=t) 0.000001)$ and a greater height than all three of the selected genotypes $(0.4303$ $\mathrm{m} ; \mathrm{P}(T<=t) 0.0002)$, followed by the Timor Hybrid $(0.00645$ $\mathrm{kg} ; \mathrm{P}(\mathrm{T}<=t) 0.0003)$ and $\mathrm{E}-146(0.00638 \mathrm{~kg} \mathrm{P}(T<=t) 0.0001)$ genotypes, with the latter having the greatest height $(0.431 \mathrm{~m}$ $\mathrm{P}(T<=t) 0.0007)$. For this reason, the Rume Sudan genotype was selected, although the tolerance index was below but very close to 1.0. Regarding root lengths, no significant differences were found among these genotypes (Table 5).
Analysis of these results shows that the Rume Sudan and Timor Hybrid genotypes are tolerant to acidity in both soil types, and therefore, they can be selected as promising candidates as progenitors in a coffee breeding program. Timor Hybrid is one of the progenitors of the Castillo variety and its regional lines, including the Castillo Naranjal variety, which was found to be moderately tolerant to the acidity of the Andisol soil, and it was classified within quadrant IV (Figure 3) but had a tolerance index very near to 1.0 (Table 3 ).

The results of various studies have demonstrated the positive effect of liming on the growth of coffee plants in the nursery stage (Pavan; Bingham; Pratt, 1982; Pavan et al., 1982; Rodrigues et al., 2001; Rodrigues et al., 2006). In this experiment, it was expected that acidity correction and increases in the contents of exchangeable bases would increase the plant biomass of all genotypes in the two soils; however, this did not occur. The lack of response by some of the plant materials may originate from the application of phosphorous, an element that facilitates root growth and, consequently, greater nutrient absorption. In addition, phosphorous can bind to $\mathrm{Al}^{3+}$ and reduce its toxicity by forming insoluble phosphates with this element (Zapata, 2014). According to the conditions of soil acidity established for coffee growing in Colombia $\left(5.0>\mathrm{pH}<5.5\right.$ and $\mathrm{Al}^{3+}$ 
$<1.10 \mathrm{cmol}_{\mathrm{c}} \mathrm{kg}^{-1}$ ), both soils were acid, being higher in the Entisol. Potassium $\left(\mathrm{K}^{+}\right)$fertilization was not included, just the amendment with dolomite to raise the $\mathrm{pH}$ greater than 5.0, neutralize $\mathrm{Al}^{3+}$ and increases $\mathrm{Ca}^{2+}$ and $\mathrm{Mg}^{2+}$. One reason to explain the high increment of $\mathrm{K}^{+}$would be the correction of acidity (Table 1). In order to improve the relationship between the bases the application of an additional dosis of dolomite would have been feasible but it would have further increased the $\mathrm{pH}$, exceeding the optimal range for coffee (Sadeghian; Díaz, 2020).
Most agricultural species are susceptible to soil acidity. This problem can be overcome by either correcting the acidity by adding liming materials or by selecting genotypes or varieties tolerant to this stress condition. The second alternative is more practical because the application of lime incurs costs and only alters the upper soil layers, causing the formation of shallow root systems in crops sensitive to acidity. The selection of tolerant genotypes allows for good yields with minimal application of lime (Howeler, 1990).

Table 3: Tolerance index of coffee genotypes grown in Entisol and Andisol, calculated using equation (1) described in the Materials and Methods section.

\begin{tabular}{|c|c|c|c|c|c|c|}
\hline \multirow{3}{*}{ GENOTYPE } & \multicolumn{3}{|c|}{ ENTISOL } & \multicolumn{3}{|c|}{ ANDISOL } \\
\hline & \multicolumn{2}{|c|}{ Dry matter $\left(\mathrm{kg} \mathrm{kg}^{-1}\right)$} & \multirow{2}{*}{$\begin{array}{l}\text { TOLERANCE } \\
\text { INDEX }\end{array}$} & \multicolumn{2}{|c|}{ Dry matter $\left(\mathrm{kg} \mathrm{kg}^{-1}\right)$} & \multirow{2}{*}{$\begin{array}{l}\text { TOLERANCE } \\
\text { INDEX }\end{array}$} \\
\hline & Acidic/Amended & Acidic/Max. Acidic & & Acidic/Amended & Acidic/Max. Acidic & \\
\hline E364 & 1.03 & 0.40 & 0.41 & 0.73 & 0.12 & 0.09 \\
\hline E365 & 0.87 & 0.39 & 0.34 & 1.25 & 0.36 & 0.45 \\
\hline E336 & 0.70 & 0.43 & 0.30 & 1.16 & 0.42 & 0.49 \\
\hline E146 & 0.58 & 0.54 & 0.31 & 1.30 & 0.86 & 1.11 \\
\hline E290 & 0.77 & 0.63 & 0.49 & 0.83 & 0.49 & 0.40 \\
\hline E085 & 1.17 & 0.61 & 0.71 & 1.55 & 0.72 & 1.12 \\
\hline E071 & 0.89 & 0.41 & 0.37 & 1.35 & 0.47 & 0.63 \\
\hline E042 & 0.70 & 0.30 & 0.21 & 1.06 & 0.53 & 0.56 \\
\hline $\mathrm{E} 428$ & 0.95 & 0.37 & 0.35 & 0.74 & 0.40 & 0.30 \\
\hline E114 & 0.66 & 0.31 & 0.20 & 0.86 & 0.45 & 0.39 \\
\hline E420 & 1.29 & 0.55 & 0.70 & 2.00 & 0.33 & 0.65 \\
\hline E554 & 0.81 & 0.41 & 0.33 & 0.92 & 0.68 & 0.62 \\
\hline ET57 & 1.57 & 0.69 & 1.08 & 0.90 & 0.49 & 0.43 \\
\hline ET06 & 1.27 & 0.74 & 0.94 & 1.00 & 0.70 & 0.70 \\
\hline ET27 & 0.59 & 0.43 & 0.25 & 1.16 & 0.65 & 0.75 \\
\hline SL-28 & 1.14 & 0.80 & 0.91 & 1.36 & 0.72 & 0.98 \\
\hline $\begin{array}{l}\text { Castillo } \\
\text { Naranjal }\end{array}$ & 0.88 & 0.78 & 0.69 & 1.11 & 0.84 & 0.93 \\
\hline S-17 Irgalem & 2.47 & 0.85 & 2.09 & 1.34 & 0.52 & 0.70 \\
\hline Timor Hybrid & 1.88 & 0.84 & 1.59 & 1.34 & 0.88 & 1.18 \\
\hline Rume Sudan & 1.55 & 1.00 & 1.54 & 0.99 & 0.99 & 0.98 \\
\hline
\end{tabular}

Table 4: C. arabica genotypes selected as tolerant to soil acidity in Entisol after analysis of the treatment effect using the quadrant method and the tolerance index.

\begin{tabular}{cccccc}
\hline \multicolumn{7}{c}{ ENTISOL } \\
\hline GENOTYPE & QUADRANT METHOD & Dry weight $(\mathrm{kg})$ & Root length $(\mathrm{m})$ & Height $(\mathrm{m})$ & TOLERANCE INDEX \\
\hline S-17 Irgalem & 4 & 0.00643 & 0.3118 & 0.3997 & 2.09 \\
Timor Hybrid & 4 & 0.00642 & 0.283 & $0.4036^{*}$ & 1.59 \\
Rume Sudan & 4 & $0.00756^{*}$ & 0.2834 & $0.4377^{*}$ & 1.54 \\
\hline
\end{tabular}

$\left.{ }^{\star}\right)$ Significant according to Student's t-test for comparison of mean dry weight, root length and height of the respective genotype with the mean of all genotypes under acidic conditions (95\% significance level). 
Table 5: C. arabica genotypes selected as tolerant to soil acidity in Andisol after analysis of the treatment effect using the quadrant method and the tolerance index.

\begin{tabular}{cccccc}
\hline \multicolumn{5}{c}{ ANDISOL } \\
\hline GENOTYPE & QUADRANT METHOD & Dry weight $(\mathrm{kg})$ & Root length $(\mathrm{m})$ & Height $(\mathrm{m})$ & TOLERANCE INDEX \\
\hline E146 & 4 & $0.00638^{*}$ & 0.255 & $0.431^{*}$ & 1.11 \\
Rume Sudan & 4 & $0.00726^{*}$ & 0.3034 & $0.4303^{*}$ & 0.98 \\
E085 & 4 & 0.00528 & 0.2526 & 0.3556 & 1.12 \\
Timor Hybrid & 4 & $0.00645^{*}$ & 0.3037 & 0.396 & 1.18 \\
\hline
\end{tabular}

(*) Significant according to Student's t-test for comparison of mean dry weight, root length and height of the respective genotype with the mean of all genotypes under acidic conditions (95\% significance level).

The availability of large germplasm collections in agricultural research centers has allowed for the evaluation of aluminum tolerance, especially in Latin America, where the percentage of acidic soils is high. To this end, several techniques have been developed for the selection of tolerant genotypes for application in breeding programs leading to the production of agricultural varieties that are tolerant to physiological stresses.

With the application of the quadrant method (Figure 1), the International Center for Tropical Agriculture (CIAT) conducted research to obtain varieties that are tolerant to acidity in agricultural crops of economic importance, such as rice, potato, soybean, peanut and cowpea. The dispersion of genotypes across the Cartesian plane quadrants of the model showed that there was variability in the tolerance to acidity in these species, and the progenies within quadrant IV were classified as being tolerant to acid with the potential for high yields (Nicholaides; Piha, 1990). By applying equation (1) with the tolerance index method, genotypes of agricultural species that produce well under high stress conditions can be selected; however, these genotypes still produce much better when lime is applied to eliminate acidity (Howeler, 1990).

Given that there is a coffee germplasm collection in Colombia and that the percentage of acidic soils in the Colombian coffee-growing regions has increased in the last 20 years, the evaluation of a core collection representing the greatest coffee germplasm variability allows for the identification of tolerant genotypes that can be used for the production of varieties with good yields in acidic soils. In this study, the accessions Rume Sudan and Timor Hybrid were selected as tolerant to soil acidity when the seedlings were grown in two types of acidic soils $(\mathrm{pH}<5.0)$ from the Colombian coffee grower region. Timor Hybrid was discovered in 1927 on a traditional coffee plantation; it is a natural hybrid resulting from interspecific crossing between $C$. arabica and C. canephora and has been used as a progenitor in several breeding programs because of its resistance to coffee rust (Castillo-Zapata; Moreno-Ruiz, 1988; Alvarado; Posada; Cortina, 2005). Rume Sudan is a semiwild variety from the Marsabit mountains in Sudan (Africa), which is resistant to coffee berry disease (Agwanda et al., 1997) and has been used as a progenitor in the production of the "centroamericano" variety released in Central America in 2008 (Quijano; Gil, 2009).

Studies conducted in Brazil have evaluated the effect of aluminum $\left(\mathrm{Al}^{3+}\right)$-induced acidity on the growth of nine commercial coffee varieties. They evaluated the effect of $\mathrm{Al}^{3+}$ on the growth of the main root in newly germinated seedlings of 26 coffee varieties and found that only the Icatu Vermelho (IAC4045) variety showed levels of tolerance to the acidic condition applied (Braccini et al., 1998; Braccini et al., 2000). These studies were performed with newly germinated seedlings under laboratory conditions using nutrient solutions that simulated acid stress.

The behavior of eight coffee varieties in acidic soils and in lime-corrected soils was evaluated in field Brazilian experiments. Using the same varieties but in hydroponic cultures, the relative tolerance index (RTI) was determined. The varieties tolerant to aluminum under hydroponic conditions corresponded to the varieties tolerant in field experiments (Mistro; Fazuoli; Gallo, 2007).

More recently, the effect of $\mathrm{Al}^{3+}$ on the seedlings of four coffee varieties grown in nutrient solutions was evaluated, and it was determined that, at least in the initial growth stages, the IAPAR 59 and Catuai amarelo IAC 62 varieties were tolerant to the effects of the acidic conditions, while the Oeiras variety showed intermediate tolerance and the Obatá IAC 1669-20 variety showed sensitivity to aluminum (Macedo et al., 2011).

The cited experiments were conducted with commercial varieties of coffee grown under environmental and edaphic conditions in Brazil, which differ from those of Colombian coffee cultivation. In particular, there have been no reports of the identification of wild C. arabica accessions in germplasm banks that may be candidate progenitors for producing genetically improved varieties that are tolerant to soil acidity. This lack of reports suggests that the early selection of genotypes may be an alternative for improvement studies of perennial species, for which obtaining a variety requires approximately 25 years. 
This study was limited to the evaluation of the dry mass of plants at 6 months of age, which did not allow for us to determine their agronomic performance in the productive stage. However, it must be taken into account that soil acidity could reduces root growth starting at the juvenile stage, leading to deficiencies in biomass production and a reduction in agricultural productivity (Liang et al., 2013). Genotypes that are selected as tolerant at an early age will probably not be affected in later stages of development, including the productive stage. However, the Rume Sudan and Timor Hybrid genotypes identified in this study as tolerant to acidity in the nursery stage will be grown under the same stress conditions and further evaluated during a production cycle to verify that acid stress has no effect on production. In such cases, these genotypes would be used in genetic crosses with commercial varieties grown in Colombia, with the purpose of initiating a genetic breeding program that would produce a new coffee variety that is tolerant to soil acidity and could be grown by Colombian coffee farmers.

\section{CONCLUSIONS}

The Coffea arabica genotypes used in breeding programs in Colombia differ in their tolerance to soil acidity.

The Timor Hybrid and Rume Sudan genotypes show tolerance to soil acidity. The tolerance of the evaluated genotypes to acidity is independent of the soil type.

\section{ACKNOWLEDGMENTS}

We are grateful to the SENA staff Diana Velasco, Sebastián Giraldo and Juan Camilo Devia for their collaboration in laboratory and field evaluations, to the extension agent Jorge Pinto and to Mr. Germán Muriel, owner of San Gil Farm, Vereda Brisas de Tonoá, municipality of Cubarral (Meta), where the soil samples were collected.

\section{REFERENCES}

AGWANDA, C. O. et al. Identification of RAPD markers for resistance to coffee berry disease, Colletotrichum kahawae, in arabica coffee. Euphytica, 97(2):241-248, 1997.

ALVARADO, G.; POSADA, H. E.; CORTINA, H. A. Castillo: Nueva variedad de café con resistencia a la roya. Avance Técnico Cenicafé, (337), 2005. Available in: http://hdl.handle.net/10778/401. Access in: August 21, 2020 .

ALVARADO, G. et al. La variedad Castillo Naranjal para las regiones cafeteras de Caldas Quindío Risaralda y Valle. Avance Técnico Cenicafé, (338), 2006. Available in: <http:// hdl.handle.net/10778/413>. Access in: August 21, 2020.
BRACCINI, M. C. L. et al. Tolerância de genótipos de cafeeiro ao alumínio em solução nutritiva. I. Crescimento e desenvolvimento da parte aérea e sistema radicular.

Revista Brasileira de Ciência do Solo, 22(3):435-442, 1998.

BRACCINI, M. C. L. et al. Rhizosphere $\mathrm{pH}$ evaluation of coffee genotypes in response to soil aluminum toxicity. Bragantia, 59:83-88, 2000.

\section{CASTILLO-ZAPATA, J.; MORENO-RUIZ, G. La variedad} Colombia: Selección de un cultivar compuesto resistente a la roya del cafeto. Chinchiná: FEDERACAFE: Cenicafé, 1988, p.171.

\section{CARRILLO, I. F. Manual de laboratorio de suelos.} Manizales: Cenicafé, 1985, p.111.

CORRÊA, J. B. et al. Índice de saturação por bases na nutrição e na produtividade de cafeeiros catuaí vermelho (Coffea arabica L.). Coffee Science, 2(2):159-167, 2007.

GAITÁN, A. et al. Almácigos de café: Calidad fitosanitaria manejo y siembra en el campo. Avance Técnico Cenicafé, (404):1-8, 2013.

HANISCH, S. et al. Soil fertility and nutrient status of traditional Gayo coffee agroforestry systems in the Takengon region, Aceh Province, Indonesia. Journal of Agriculture and Rural Development in the Tropics and Subtropics, 112(2):87-100, 2012.

HAVLIN, J. L. et al. Soil fertility and fertilizers: An Introduction to nutrient management. 8.ed, Pearson Education India, 2014, 516p.

HOWELER, R. Effective selection techniques to seek tolerance to aluminum toxicity. In: GOURLEY, L.; SALINAS, J. Sorghum for acid soils. Workshop on the Evaluation of sorghum due to its tolerance to tropical soils in Latin America that contain Aluminio tóxico (1984), Cali, Colombia. Centro Internacional de Agricultura Tropical (CIAT), p. 179-195. 1990. Available in: $<$ http:// ciat-library.ciat.cgiar.org/Articulos_Ciat/Digital/SB191. S7_S635_Workshop_on_Evaluating_Sorghum_for_ Tolerance_to_AI-toxic_Tropical_Soils_in_Latin_ Am.pdf $>$. Access in May 13, 2020.

LIANG, C. et al. Low pH, Aluminum, and Phosphorus Coordinately Regulate Malate Exudation through GmALMT1 to Improve Soybean Adaptation to Acid Soils. Plant Physiology, 161(3):1347-1361, 2013.

MACEDO, C. M. P. et al. Tolerance of arabica coffee cultivars for aluminum in nutritive solution. Brazilian Archives of Biology and Technology, (54):885-891, 2011. 
MISTRO, J. C.; FAZUOLI, L. C.; GALLO, P. B. Comportamento de cultivars de café arabica em solos ácidos corregidos. O Agronómico, 59:37-38, 2007.

NICHOLAIDES, P.; PIHA, C. A new methodology to select cultivars tolerant to aluminum and with high yield potential. In: GOURLEY, L.; SALINAS, J. Sorghum for acid soils. Workshop on the Evaluation of sorghum due to its tolerance to tropical soils in Latin America that contain Aluminio tóxico (1984), Cali, Colombia. Centro Internacional de Agricultura Tropical (CIAT), p. 109122, 1990. Available in: <http://ciat-library.ciat.cgiar. org/Articulos_Ciat/Digital/SB191.S7_S635_Workshop_ on_Evaluating_Sorghum_for_Tolerance_to_AI-toxic Tropical_Soils_in_Latin_Am.pdf $>$. Access in: August 22, 2020 .

PAVAN, M. A. et al. Toxicity of aluminium seedling to coffee grown in nutrient solution. Soil Science Society of America Journal, 46(5):993-997, 1982.

PAVAN, M. A.; BINGHAM, F. T.; PRATT, P. F. Toxicity of Aluminum to Coffee in Ultisols and Oxisols Amended with $\mathrm{CaCO}_{3}, \mathrm{MgCO}_{3}$ and $\mathrm{CaSO}_{4} 2 \mathrm{H}_{2} \mathrm{O}$. Soil Science Society of America Journal, 46(6):12011207, 1982.

QUIJANO, J.; GIL, S. Conozca la variedad del café "centroamericano" para la caficultura del futuro. Hoja Tecnica, PROCAFÉ, febrero 6, 2009. Available in: $<$ https://www.yumpu.com/es/document/read/14490317/ conozca-la-variedad-de-cafe-centroamericano-procafe- $>$. Access in: May 13, 2020.

RAO, I. M. et al. Selection and breeding for acid-soil tolerance in crops. BioScience, 43(7):454-465, 1993.

RAO, I. M. Advances in improving adaptation of common bean and Brachiaria forage grasses to abiotic stress in the tropics. In: PESSARAKLI, M. Handbook of plant and crop physiology. USA: CRC Press, 2014, p.847889.

RAO, I. M. et al. Root adaptations to soils with low fertility and aluminium toxicity. Annals of Botany, 118(4):593$605,2016$.
RHEINHEIMER, D. S. et al. Aplicação superficial de calcário no sistema plantio direto consolidado em solo arenoso. Ciência Rural, 30(2):263-268, 2000.

RODRIGUES, L. A. et al. Growth response of coffee tree shoots and roots to subsurface liming. Plant Soil, 234(2):207-214, 2001

RODRIGUES, L. A. et al. Respostas nutricionais de cafeeiros catuaí e icatu a doses de calcário em subsuperfície. Revista Brasileira de Ciencia do Solo, 30(6):985-995, 2006.

SADEGHIAN, S. Fertilidad del suelo y nutrición del café en Colombia: Guía practica. Boletín técnico, (32):43, 2008.

SADEGHIAN, S. Nutrición de cafetales. In: FEDERACIÓN NACIONAL DE CAFETEROS DE COLOMBIA. Manual Del Cafetero Colombiano: Investigación y Tecnología Para La Sostenibilidad de La Caficultura. CENICAFE, Chinchiná, 2013, v.2, p.85-86.

SADEGHIAN, S.; DÍAZ, V. C. Corrección de la acidez del suelo: Efectos en el crecimiento inicial del café. Revista Cenicafé, 71(1):21-31, 2020.

VALENCIA, A. G. Fisiología, nutrición y fertilización del cafeto. Manizales: CENICAFE: Agroinsumos del Café, 1999, p.94.

VALENCIA, A. G.; BRAVO E. Influencia del encalamiento en la producción de cafetales establecidos. Revista Cenicafé, 32(1):3-14, 1981.

VILELA, L. C. et al. Propriedades químicas de Latossolo Vermelho em função da aplicação de gessagem e calagem. Revista Acadêmica Ciência Animal, 8(1):19-27, 2010.

YANG, Z. B.; RAO, I. M.; HORST, W. J. Interaction of aluminium and drought stress on root growth and crop yield on acid soils. Plant and Soil, 372(3):3-25, 2013.

ZAPATA, H. R. Química de la acidez del suelo. Cargraphics: Cali., 2004, p.208.

ZAPATA, H. R. Los procesos químicos del suelo. Medellín, Colombia: Editorial Universidad Nacional, 2014, p.686. 